\title{
Solar Architecture Integrated Bi-Facial Photovoltaic System as a Shade
}

\author{
Seung-Ho Yoo ${ }^{1, *(\mathbb{D})}$ and Hee-Jeong Choi ${ }^{2}$ \\ 1 Solar Architecture Laboratory, Sehan University, Younagam 58447, Korea \\ 2 Department of Biosystems and Convergence Engineering, Catholic Kwandong University, \\ Gangneung-si 25601, Korea; hjchoi@cku.ac.kr \\ * Correspondence: energy@unitel.co.kr
}

check for

updates

Citation: Yoo, S.-H.; Choi, H.-J. Solar Architecture Integrated Bi-Facial Photovoltaic System as a Shade. Processes 2021, 9, 1625. https:// doi.org/10.3390/pr9091625

Academic Editor: Sara Pescetelli

Received: 2 August 2021

Accepted: 29 August 2021

Published: 9 September 2021

Publisher's Note: MDPI stays neutral with regard to jurisdictional claims in published maps and institutional affiliations.

Copyright: (c) 2021 by the authors. Licensee MDPI, Basel, Switzerland. This article is an open access article distributed under the terms and conditions of the Creative Commons Attribution (CC BY) license (https:// creativecommons.org/licenses/by/ $4.0 /)$.

\begin{abstract}
Solar architecture is defined as a kind of building integrated photovoltaic (BIPV) in which the PV modules are deployed to passive solar concepts, to minimize the heating and cooling load, to upgrade the indoor environment, and to be adjustable for regional weather and to continuously succeed architectural culture. Solar architecture needs to consider the architectural culture and climate of the region through an ecological convergence. The ecological criteria lead to optimizing solar architecture through an ecological convergence of a passive intelligence and renewable energy system. The optimal angle of the bi-facial PV module as a shade is $23.5^{\circ}$ considering the physical interaction and the traditional architecture in Korea according to the ecological criteria. The shading concept of the PV module reduces $27.5 \sim 34 \%$ of the building cooling load. Effective solar irradiance (ESR) is very important not only for PV efficiency but also for the system usage rate. This ESR should be controlled depending on the climate condition to maximize the total energy elimination factor and total energy transmittance factor for a window. The MB-BIPVS play an excellent role to maximize the total energy elimination factor and total energy transmittance factor for a window.
\end{abstract}

Keywords: passive intelligence; multi-functional BIPV; Bi-facial PV module; building energy conservation

\section{Introduction}

There are various strategies to design environmentally friendly and sustainable buildings in many different countries. A large portion of energy is used for heating and cooling buildings: approximately $25 \%$ in Korea, $50 \%$ in the USA, and $40 \%$ in Europe [1]. Many photovoltaic systems used to be simply installed just to generate electricity in many countries. It is very important from the ecological point of view that the PV systems are installed ecologically in existing or newly planned buildings according to strategically adjustable methods to generate electricity, to reduce cooling and heating load of buildings, to protect noise, to maximize the use of daylight, and to improve thermal comfort, etc. [2,3]. The 5 different institutes including the new renewable energy committee (NREC, Apr. 2008 Feb. 2012) in the architectural institute of Korea (AIK), the Korean Solar Energy Society (KSES, Jun. 2013 present), the Korean Society of Living Environment System (KSLES, Feb. 2013 present), KIAEBS (Jun. 2011), and KOPIA (Jun. 2011) have presented and discussed together the assessing standard and the data needed for this solar architecture, which we have suggested based on a theoretical background from building physics such as heat, light and acoustics to deploy an environment-friendly photovoltaic system in a form of forum [4], workshop [5] and symposium [6]. Other research has shown that lighting electricity for a high-rise building can be supplied by photovoltaic panels in the building, which work in a combination of facades [7].

This paper describes the ecological processes to optimize solar architecture by using ecological criteria through an ecological convergence of a passive solar architecture and photovoltaic system. A high-rise apartment with a solar architecture integrated bifa- 
cial photovoltaic (BIPV) system as a shade is evaluated by ecological design criteria for solar architecture.

\section{Materials and Methods}

The Solar Architecture is defined as a kind of building integrated photovoltaic (BIPV) in which the PV modules are deployed toward passive solar concepts, to minimize the heating and cooling load, to upgrade the indoor environmental quality, and to be adjustable for regional weather and to continuously succeed architectural culture. The most ideal form of solar architecture is a multi-functional and ecological convergence with a passive solar concept application of a photovoltaic module for a building. Solar Architecture needs to consider the architectural culture of the region through an ecological convergence that is applicable to a passive concept if the environmental, energy, and comfort problems will be effectively mitigated. The evaluation criteria are also needed to fulfill these requirements of the solar architecture. Each evaluation factor of the evaluation criteria needs an evaluation tool. The simulation program SOLCEL has been developed to simulate the evaluation factors including multifunctional bi-facial BIPV as a shade (MB-BIPVS). This is one of the best tools to evaluate Solar Architecture [3,8,9].

Figure 1 shows the structure of the simulation program SOLCEL [8].

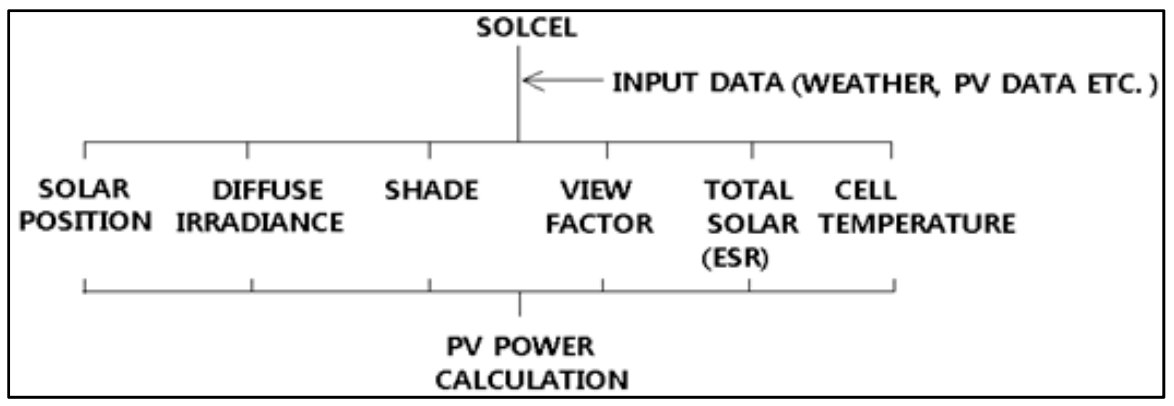

Figure 1. The structure of the simulation program SOLCEL.

The MB-BIPVS could have been simulated since 2019. Regional weather data and PV data, etc., are used as input data. The main focus of this version 19 is MB-BIPVS which can simulate all possible reflectance from the wall, window, cell, ground, and neighbor building. The reflectance solar ray is calculated by the sub-routine "VIEW FACTOR" in Figure 1.

Table 1 shows the ecological design criteria also for solar architecture integrated bi-facial photovoltaic.

Table 1. Ecological design criteria for Solar Architecture Integrated Bi-facial Photovoltaic.

\begin{tabular}{|c|c|c|c|c|}
\hline Category & \multicolumn{2}{|c|}{ Evaluation Factor } & Remarks & Score \\
\hline $\begin{array}{l}\text { Solar Radiation }(\times 1) \\
\quad(1 \text { Item: } 20 \%)\end{array}$ & \multicolumn{2}{|c|}{ Effective Solar Irradiance (ESR) } & Effective Solar Irradiance Factor & 20 \\
\hline \multirow{6}{*}{$\begin{array}{l}\text { Energy }(\times 2) \\
(3 \text { Items: } 21 \%)\end{array}$} & \multicolumn{2}{|c|}{$\begin{array}{c}\text { Energy Conservation through Natural } \\
\text { Ventilation }\end{array}$} & Natural Ventilation & 3 \\
\hline & \multirow{3}{*}{$\begin{array}{l}\text { Heating \& Cooling } \\
\text { Load Reduction }\end{array}$} & \multirow{2}{*}{ Transparent Envelope } & Total Energy Elimination Factor: 5 & \multirow{3}{*}{12} \\
\hline & & & Total Energy Transmittance Factor: 5 & \\
\hline & & Opaque Envelope & Thermal Conductance: 2 & \\
\hline & \multirow{2}{*}{\multicolumn{2}{|c|}{$\begin{array}{l}\text { Consideration for Power Generation } \\
\text { Improvement }\end{array}$}} & No shaded Area on Module: 3 & \multirow{2}{*}{6} \\
\hline & & & Convergence idea: 3 & \\
\hline
\end{tabular}


Table 1. Cont.

\begin{tabular}{|c|c|c|c|c|}
\hline Category & \multicolumn{2}{|c|}{ Evaluation Factor } & Remarks & Score \\
\hline \multirow{2}{*}{$\begin{array}{l}\text { Aesthetic View }(\times 3) \\
\quad(1 \text { Item: } 10 \%)\end{array}$} & \multirow{2}{*}{\multicolumn{2}{|c|}{$\begin{array}{l}\text { Harmony with Architecture or building } \\
\text { Envelope }\end{array}$}} & Harmony with Architecture: 5 & \multirow{2}{*}{10} \\
\hline & & & Finish Material: 5 & \\
\hline \multirow{4}{*}{$\begin{array}{c}\text { Indoor Environmental } \\
\text { Quality }(\times 4) \\
\text { (3 Items: } 15 \%)\end{array}$} & Acoustic Env. & Puffer factor & Puffer factor against outside noise & 5 \\
\hline & Thermal Env. & Thermal Comfort & Operative Temperature & 5 \\
\hline & \multirow[t]{2}{*}{ Lighting Env. } & $\begin{array}{l}\text { Sunshine Hour in } \\
\text { Room }\end{array}$ & Daylight factor & 2 \\
\hline & & Glare & Glare protection & 3 \\
\hline \multirow{4}{*}{\multicolumn{2}{|c|}{$\begin{array}{l}\text { Maintenance }(\times 5) \\
\quad(4 \text { Items: } 17 \%)\end{array}$}} & $\begin{array}{l}\text { Building Energy } \\
\text { Management system }\end{array}$ & Smart building management system & 5 \\
\hline & & Monitoring & PV monitoring system & 5 \\
\hline & & Continuity of ESR & Same effective solar irradiance & 4 \\
\hline & & $\begin{array}{l}\text { Cleaning for Module } \\
\text { Surface }\end{array}$ & Smart Sensors & 3 \\
\hline \multirow{2}{*}{\multicolumn{2}{|c|}{$\begin{array}{l}\text { Practical Use of Structure }(\times 6) \\
\text { (2 Items: } 6 \%)\end{array}$}} & $\begin{array}{l}\text { Application for a New } \\
\text { Building }\end{array}$ & Ecological application for new build. & 3 \\
\hline & & $\begin{array}{l}\text { Application for a } \\
\text { Remodeling }\end{array}$ & Application for old building & 3 \\
\hline \multirow{2}{*}{\multicolumn{2}{|c|}{$\begin{array}{l}\text { Safety }(\times 7) \\
(2 \text { Items: } 4 \%)\end{array}$}} & Fire Resistance & & 2 \\
\hline & & Impact Intensity & & 2 \\
\hline \multicolumn{2}{|c|}{$\begin{array}{l}\text { Environmental Friendliness }(\times 8) \\
\qquad(1 \text { Item: } 7 \%)\end{array}$} & $\begin{array}{c}\mathrm{CO}_{2} \text { Evaluation } \\
\text { through Life Cycle } \\
\text { Analysis of a System }\end{array}$ & $\mathrm{LCCO}_{2}$ & 7 \\
\hline \multicolumn{2}{|c|}{8 Categories $(100 \%)$} & 17 Evaluation Factors & $\begin{array}{c}\text { 1st Grade: } 90,2 \text { nd Grade: } 80 \text {, } \\
\text { 3rd Grade: } 70\end{array}$ & 100 \\
\hline
\end{tabular}

The evaluation methods for the evaluation factors and remarks in Table 1 are mostly described in the previous articles [9].

An intensive interest in the bi-facial PV has been also given to the PV area by various researchers [10-12].

A high-rise apartment is selected as a target building for an evaluation. Various building integrated photovoltaic systems with different variables are deployed in this high-rise apartment for comparison. There are also some criteria for the assessment of BIPV [13].

\section{Results}

\subsection{Target Solar Apartment Evaluation Subsection}

3.1.1. The Target Solar Apartment for an Analysis

The target solar apartment is located near Seoul, the Republic of Korea. It is a 28-story apartment. The construction started in May 2020 and it will be completed in September 2022.

The target apartment building faces southeast $\left(160^{\circ}\right)$ and is located in the center of the complex as seen in Figure 2.

Figure 3 shows the perspective view of the target apartment and total block. 


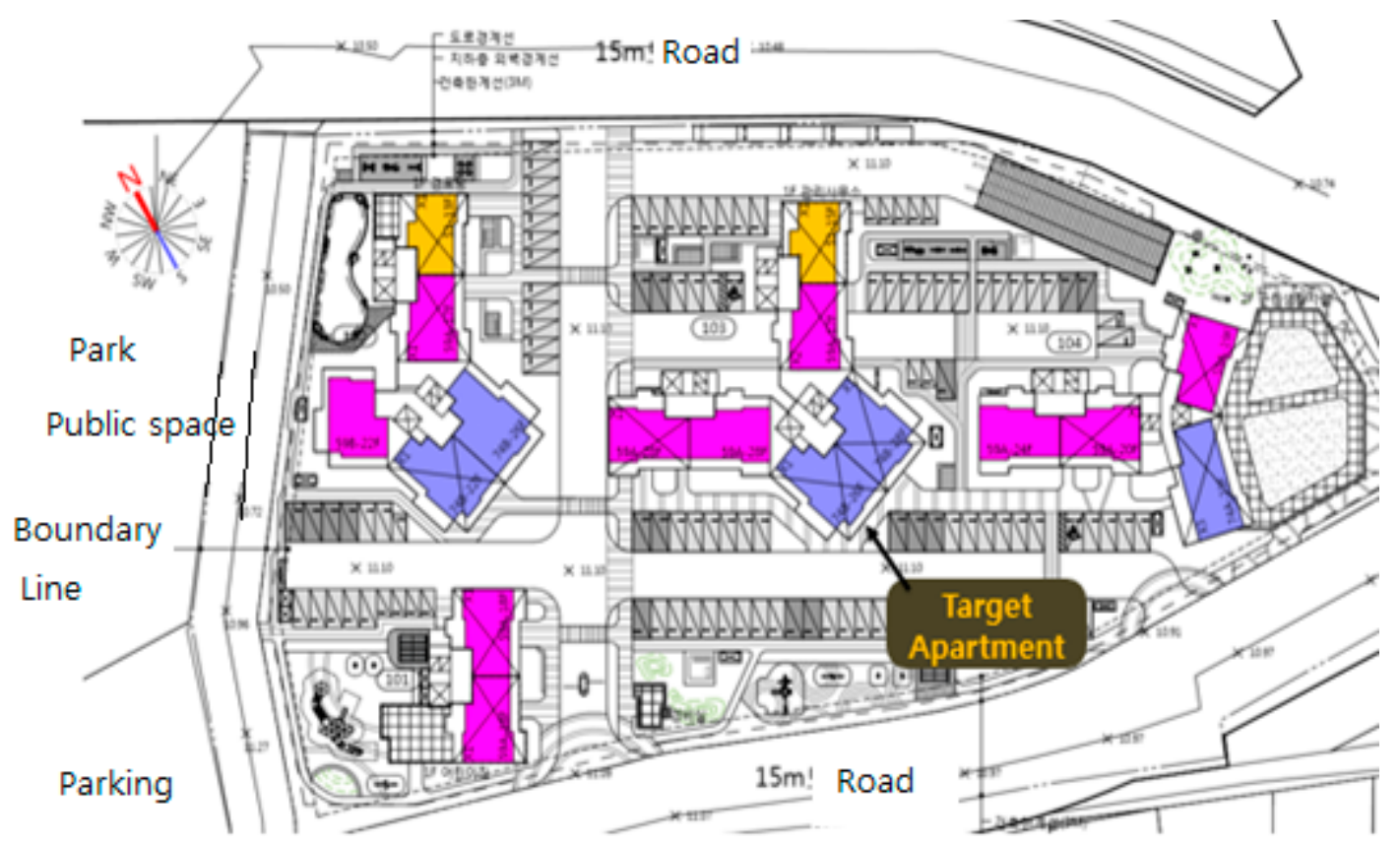

Figure 2. The site plan for the target apartment.

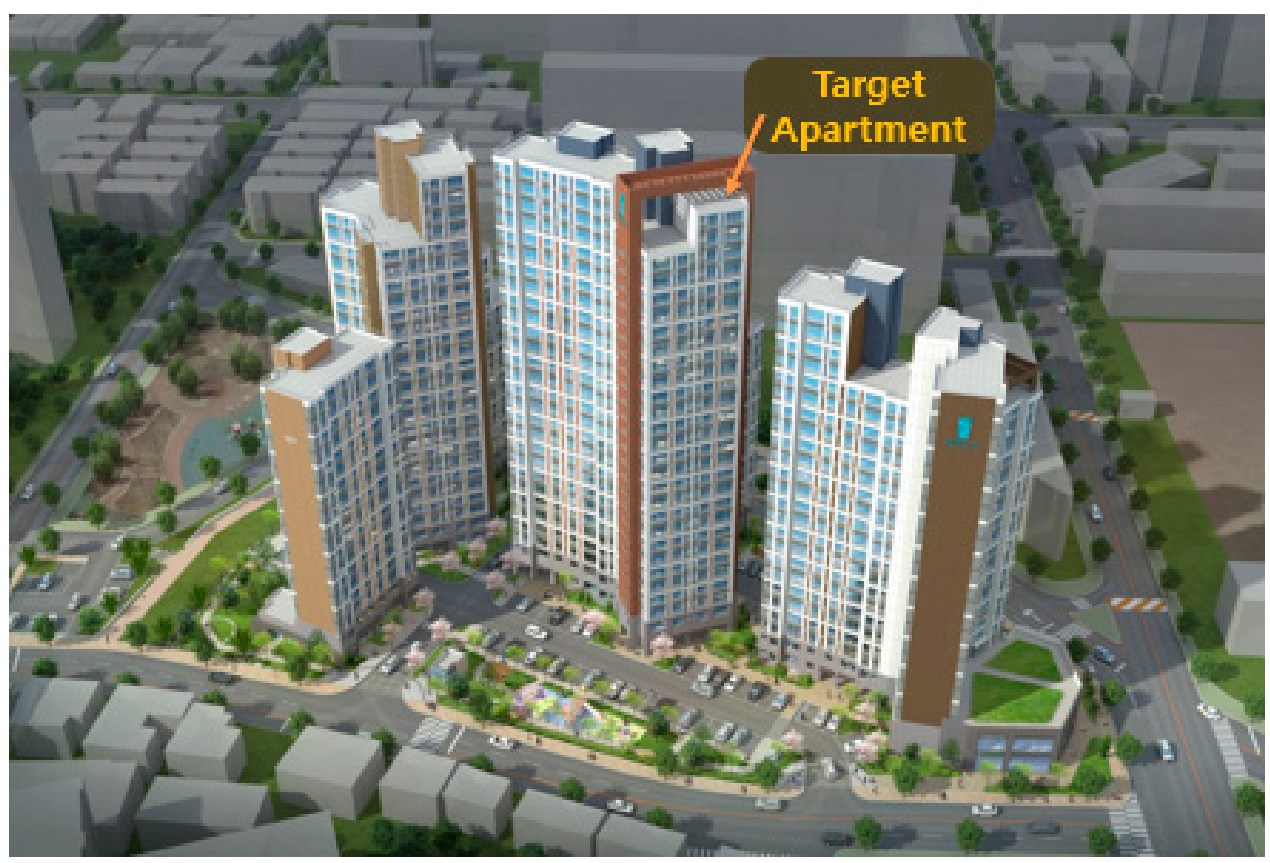

Figure 3. The perspective view of the target apartment and total block.

The floor height is 28 stories, which is the highest plan in the complex.

Figure 4 shows the unit floor plan of the target apartment.

The southeast façade of the apartment is planned to a window which should be shaded by a PV module to reduce the cooling load. The MB-BIPVS faces the southeast façade of the apartment, which functions as an eave of a traditional Korean house by a PV module to reduce the cooling load for the cooling season.

The multi-functional building integrated bifacial photovoltaic as a shade (MB-BIPVS) was planned from the top to the 9 th floor, and this floor plan is the reference one where the MB-BIPVS will be planned. 


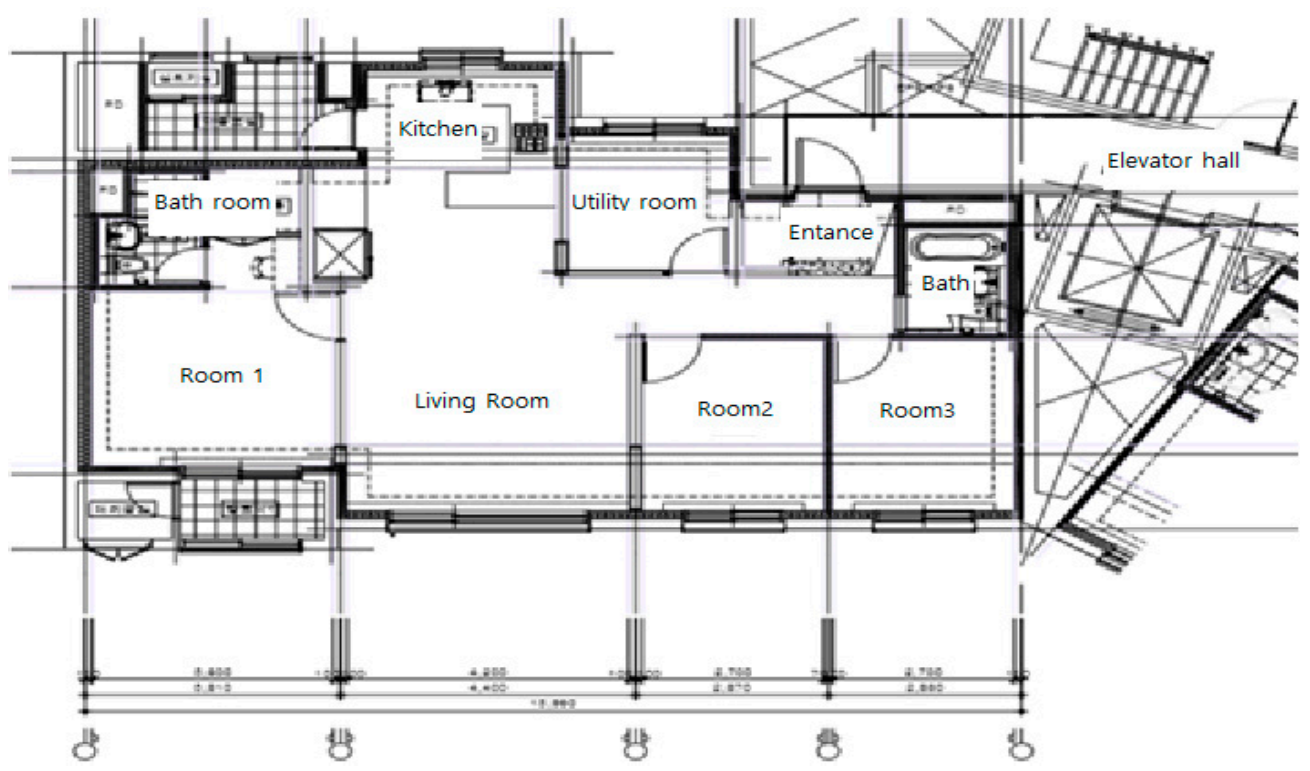

Figure 4. The unit floor plan of the target apartment.

\subsubsection{The Concept of the MB-BIPVS for the Target Apartment}

The key concepts for this research are mainly oriented towards passive intelligence that tries to explore the real situations and the hidden natural energy sources for a passive solar apartment, based on educated guesses supplemented by modeling to avoid solutions that may not be ecological in the context of sustainability. The passive intelligence of the $\mathrm{PV}$ module considers an eave of the traditional architecture in Korea to reduce the cooling load, to maximize PV power generation. Figure 5 shows the concept of the MB-BIPVS section of the target apartment.

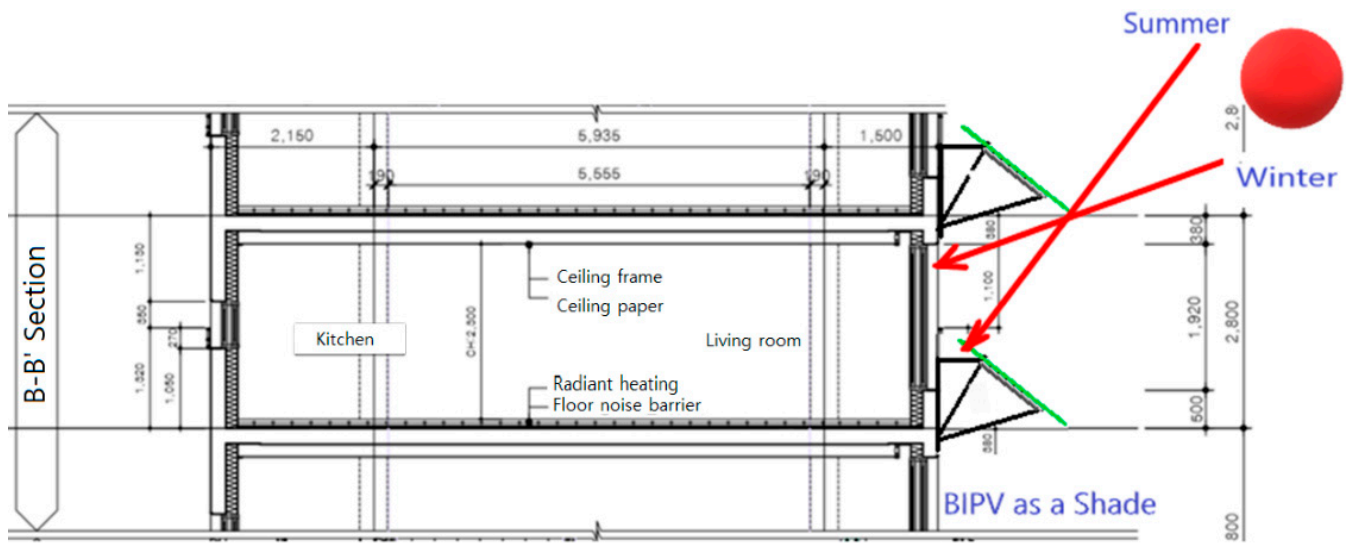

Figure 5. The concept of the MB-BIPVS for a section of the target apartment.

The cooling capacity of the renewable radiative cooling system that will be deployed in this passive solar apartment can be minimized by applying the principle of the eave, applying the bi-facial BIPV as a shade (acting as eave). This concept reduces the cooling load by $34 \%$ just by the eave in Seoul, Korea [3]. Figure 6 shows the principle of the eave and the energy harvesting for the bi-facial PV module on the target apartment [3]. 


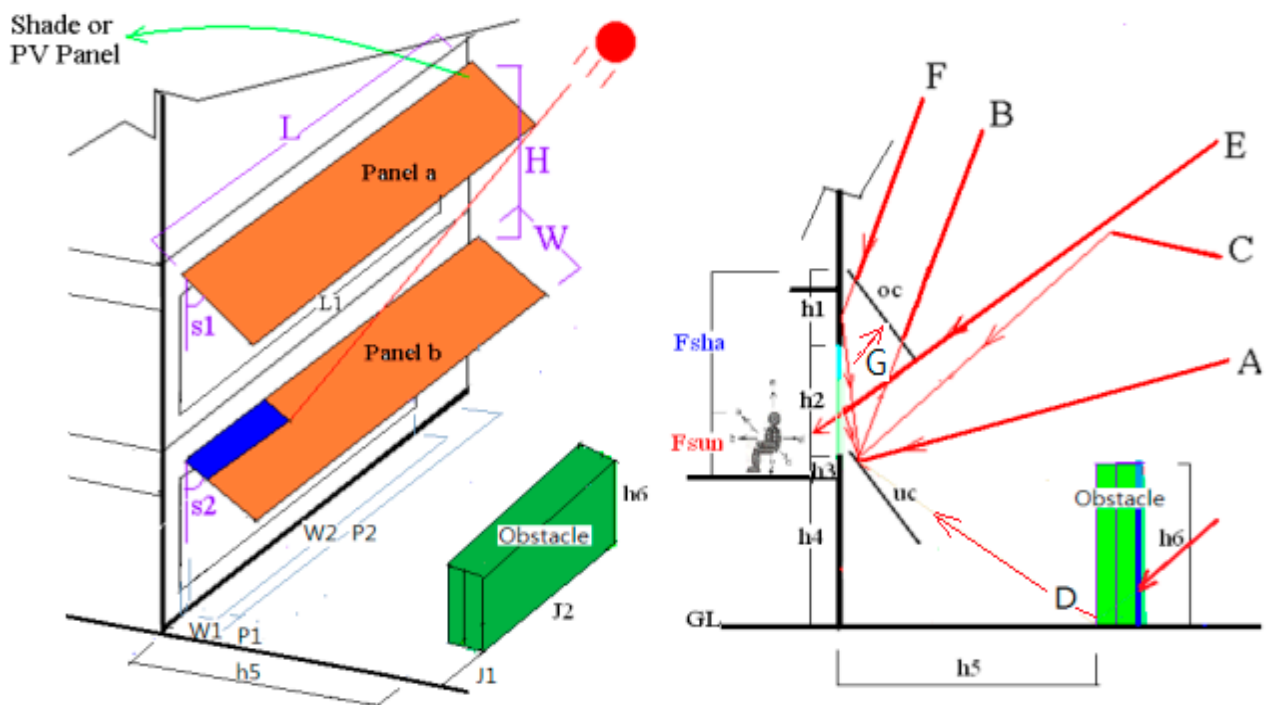

Figure 6. The principle of the eave and the energy harvesting for the bi-facial PV module.

A graphical view of solar reflectance is explained in Figure 6. The simulation program "SolCel" has been developed by the concept of Figure 6.

The alphabet A to $\mathrm{G}$ describes all possible solar rays that the simulation program SOLCEL calculates. The alphabet $\mathrm{G}$ means the reflected solar irradiance from the wall, window, solar cell, and ground surface. The alphabet $C$ means the diffuse irradiance. The sum of A to G means effective solar irradiance (ESR) in Table 1. Because bifacial solar cells can generate electrical power, not only through the front but also through the rear, the MB-BIPVS can be very well combined with a bi-facial solar cell rather than a crosssectional solar cell. As reflected light and scattered light reach the rear of the solar cell, the module contributes to the power generation output, the daily power at the same time as the instantaneous maximum power value increases. This is why most of the increase in the total solar radiation incident on the front and back of the bifacial solar cell module compared to the cross-section shows the output characteristics reflected by an increase in current.

Figure 7 shows the perspective view with the color MB-BIPVS on the south side of the target apartment.

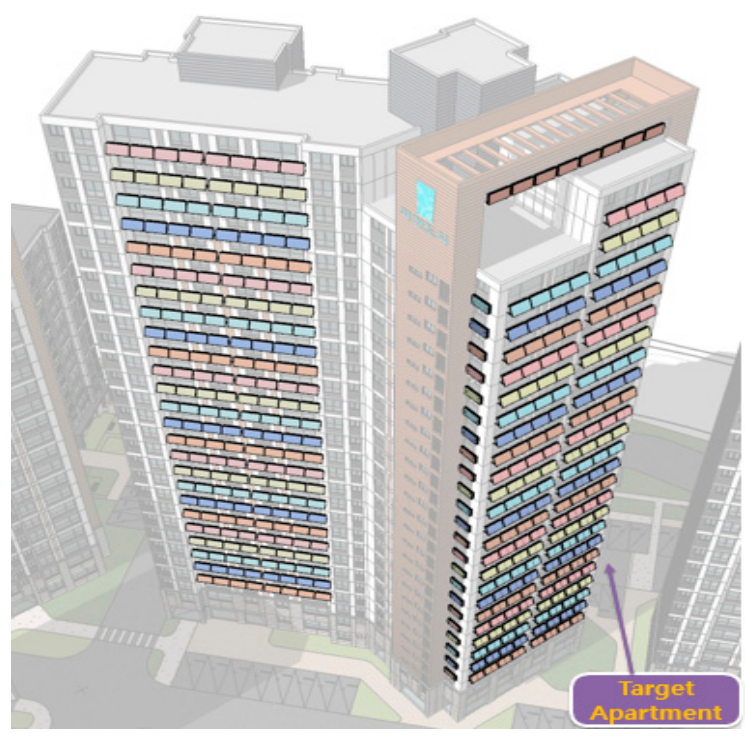

Figure 7. The perspective view with the color MB-BIPVS on the south side of the target apartment. 


\subsubsection{The Target Apartment Variables for Simulation}

The variables for the target apartment which will be simulated are in Table 2. A photovoltaic system is planned as a shading device on the south façade of the target apartment. The simulation for the target apartment is done by the simulation program "SolCel" which has been developed since 2011 [3,8]. Table 2 shows the parameter variables as input data for the simulation of the target apartment to compare with each other.

Table 2. Parameter variables for the simulation of the target apartment.

\begin{tabular}{|c|c|c|}
\hline Variables & Value & Remarks \\
\hline Building latitude (Degree) & 37.5 & \\
\hline Azimuth (Degree) & 160 & \\
\hline Longitude & $126.6 \mathrm{E}$, & \\
\hline \multirow{2}{*}{ PV module angle (Degree) } & Shade type: 23.5 & \\
\hline & Wall attached: 90 & \\
\hline Cell type & Mono crystalline & \\
\hline Standard efficiency (\%) & 16.44 & \\
\hline System type & Grid connected & \\
\hline Maximum output $\left(\mathrm{P}_{\max }\right)\left(\mathrm{W}_{\mathrm{p}}\right)$ & 265 & $\pm 3 \%$ \\
\hline $\begin{array}{l}\text { Unit module dimension } \\
(\text { Width } \times \text { Length } \times \text { Depth })(\mathrm{mm})\end{array}$ & $\begin{array}{c}1643 \times 981 \times 40 \\
\left(\text { Unit module area: } 1.6 \mathrm{~m}^{2}\right)\end{array}$ & - \\
\hline PV area (Width $\times$ Length $\times$ Floor $)(m m)$ & $\begin{array}{c}12,000 \times 1000 \times 19 \\
\left(228 \mathrm{~m}^{2}\right)\end{array}$ & $\begin{array}{l}\text { Bi-facial } \\
\text { Single }\end{array}$ \\
\hline $\begin{array}{l}\text { Transmittance, Depth, thermal } \\
\text { conductance of PV Cell }\end{array}$ & $0.01,4,3.5$ & \\
\hline Absorbance, reflectance of PV cell & $0.9,0.1$ & \\
\hline Temperature coefficient of PV module (\%) & 0.3 & \\
\hline Transmittance, emittance of module glass & $0.8,0.9$ & \\
\hline Albedo of earth & 0.3 & \\
\hline Reflectance and emittance of wall & $0.3,0.9$ & \\
\hline Reflectance of window & 0.2 & \\
\hline Ratio of cell in module & 0.85 & \\
\hline Room temperature(Degree) & 20,28 & \\
\hline
\end{tabular}

\subsection{MB-BIPVS Simulation for the Solar Apartment}

The MB-BIPVS system is planned to attach from the 28th floor to 9th floor. The simulation program "SolCel" is used, continuously developing to simulate the obstacles in front of a building, including a bi-facial PV module, an effective solar irradiance factor, and a thermal comfort in an adjacent room of BIPV as a shading as per Figure 6 in the Section 3.1.2. However, the influence of adjacent buildings on reflectance is not considered in this apartment simulation. Since the apartment is planned near Seoul, the simulation was performed using the weather data of the Seoul area. The hourly global solar irradiance, wind speed, and air temperature are used as input data for SolCel. Figure 8 shows the simulation results for a power generation depending on the angle change of the BIPV module. 


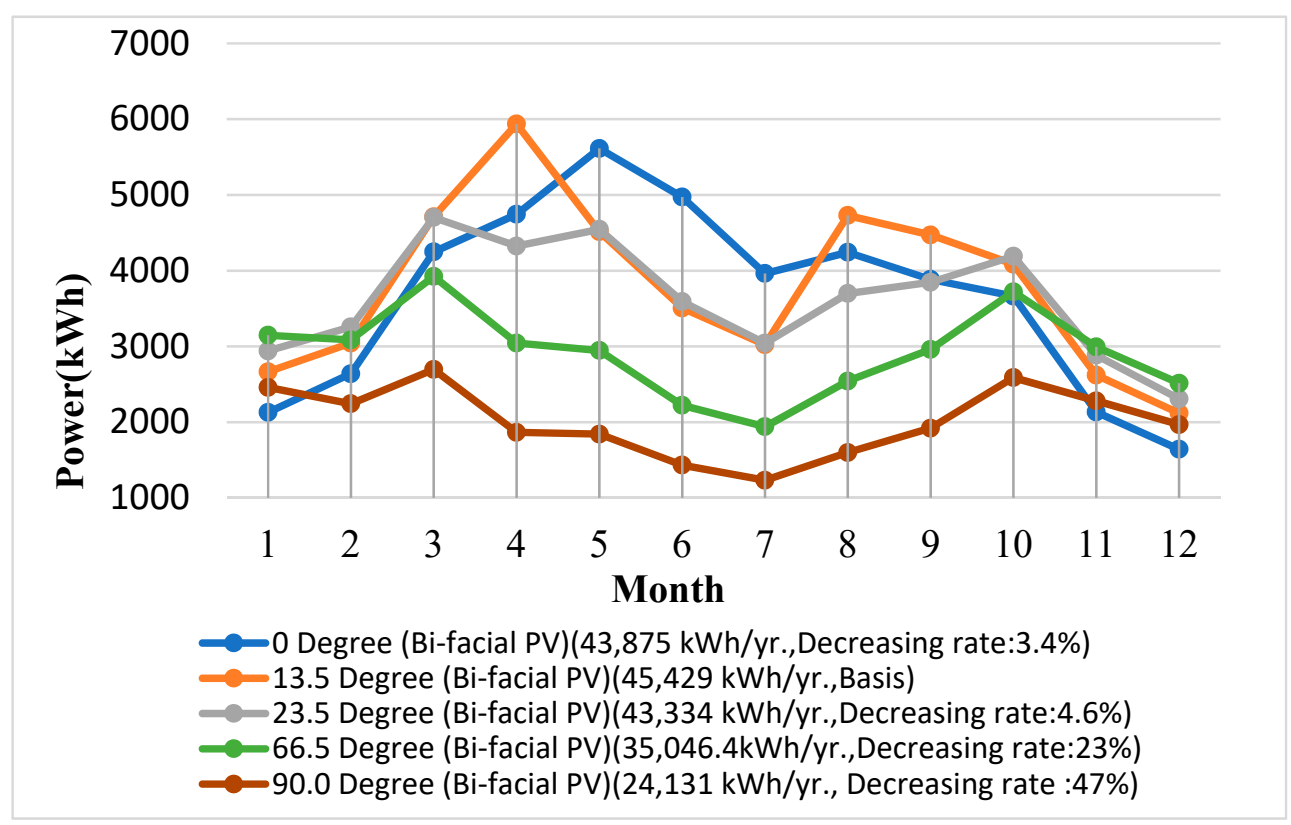

Figure 8. The simulation results for a power generation depending on the angle of the PV module.

The optimal angle of the bi-facial PV module is $13.5^{\circ}$. However, the application angle of the PV module for this apartment is $23.5^{\circ}$ considering an aesthetical view based on the architectural culture in Korea. The angle of an eave in which we can see in the traditional architecture of Korea is $23.5^{\circ}$. Much experienced knowhow through several generations which we could take into account is contained in the traditional architecture. This aesthetic view $(\times 3)$ in the ecological design criteria of Table 1 can be recommended to choose depending on the region in which an apartment will be designed considering the optimal angle of a BIPV system. Figure 9 shows the power generation depending on PV module type (Single and Bi-facial PV) and reflectance (0.1 and 0.2) of the PV cell under the PV angle $23.5^{\circ}$.

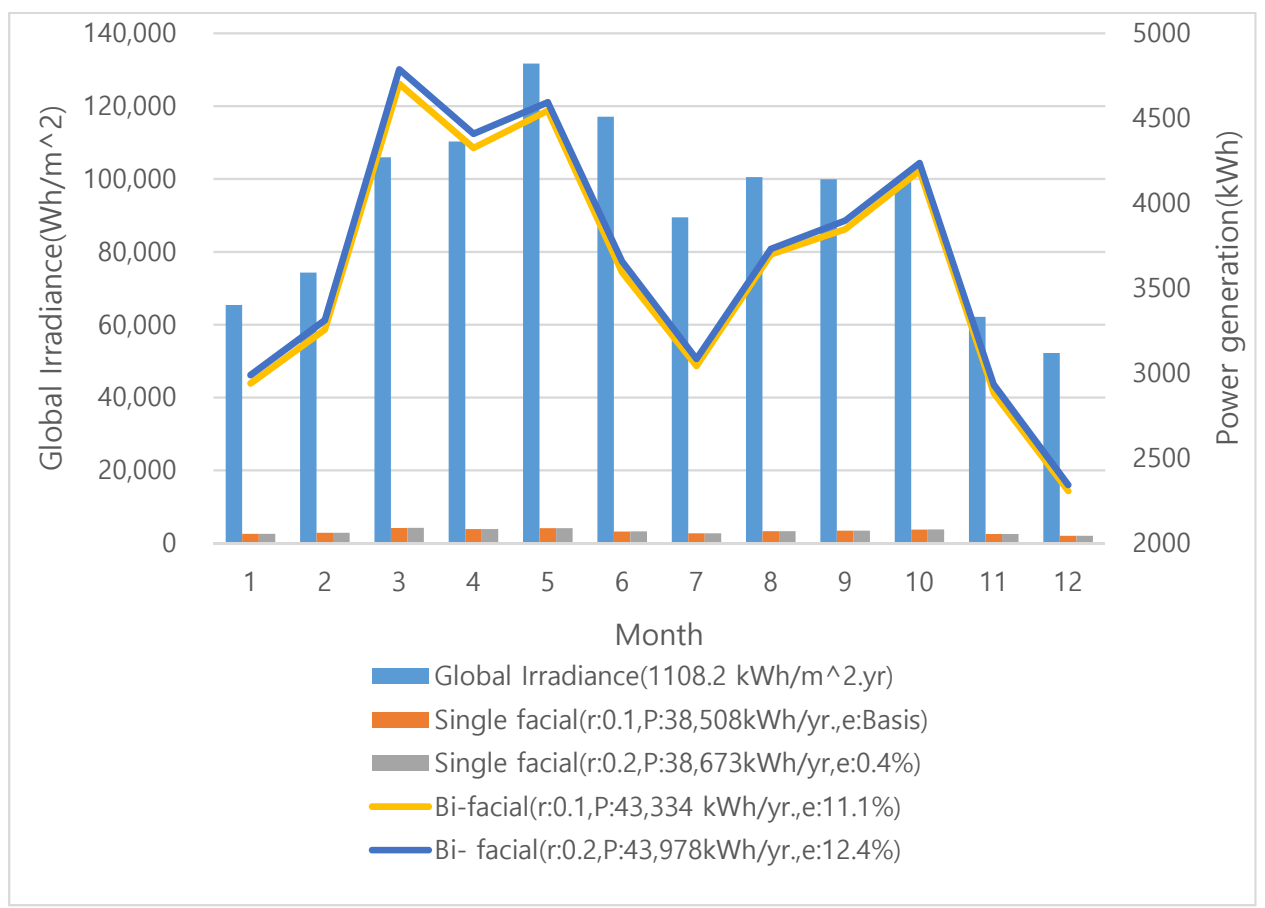

Figure 9. The power generation depending on PV module type and reflectance of the PV cell. 
The power generation of the single facial BIPV system depending on the reflectance rate (from $r=0.1$ to 0.2 ) of the PV module surface increases $0.4 \%$. However, in the case of the bi-facial BIPV system, the power generation increases $1.3 \%$ between the two types of PV module due to reflectance from the wall surface, window, and the other PV module; and the Bifacial BIPV modules can produce $12 \%$ additional output energy in comparison to a conventional mono-facial BIPV system because both sides of the cell/module, front, and rear, can absorb solar radiation, utilizing the scattered light from the ground and surroundings.

Figure 10 shows the system usage rate depending on the PV module type (bi-facial PV) and reflectance (0.1) of the PV cell under the PV angle $90^{\circ}$.

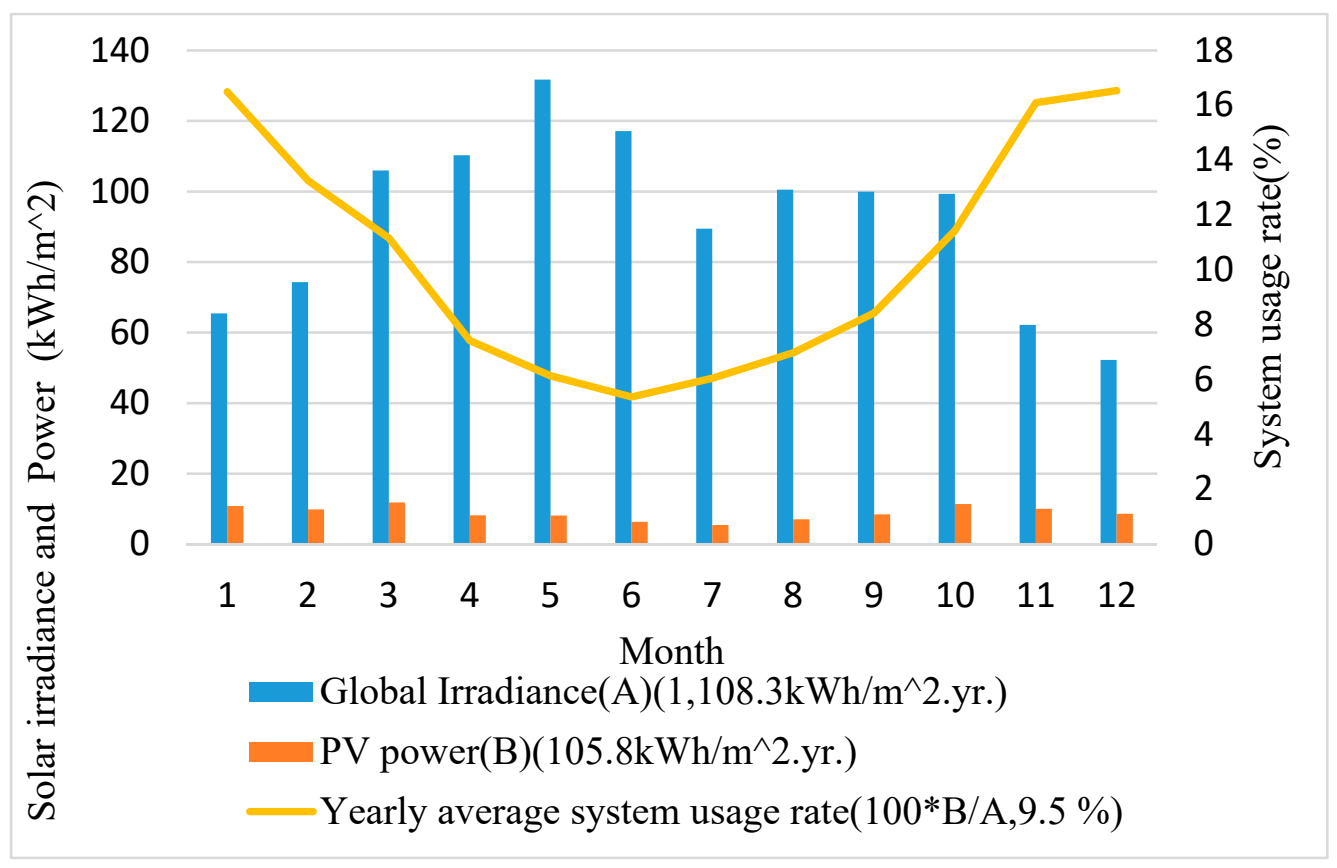

Figure 10. The system usage rate of the bi-facial BIPV module under the PV angle $90^{\circ}$.

The system usage rate $(100 \times$ Power generation/Global irradiance $)$ of the wall attached PV system shows just $5.4 \%$ in June which represents the highest solar altitude among 12 months. The yearly average system usage rate is also relatively low for these reasons, corresponding to $9.5 \%$. Figure 11 shows the system usage rate depending on the PV module type (Bi-facial PV) and reflectance (0.1) of the PV cell under the PV angle $23.5^{\circ}$.

The system usage rate of this PV system as a shade shows relatively uniform power distribution all year round independent of the solar altitude variation among the 12 months. The yearly average system usage rate is also relatively high for these reasons, corresponding to $17.6 \%$. The increased power output caused by the uniform system usage rate $(17.6 \%)$ of the bi-facial BIPV as a shade is $46 \%$ more than one by the low system usage rate $(9.5 \%)$ of the wall attached bi-facial BIPV system, because bifacial PV cells can generate electrical power, not only through the front but also through the rear, coming from the wall surface, window, and surroundings, etc. These results are described as the ESR in Table 1. The global irradiance $\left(105 \mathrm{kWh} / \mathrm{m}^{2}\right)$ in March is less than that $\left(117 \mathrm{kWh} / \mathrm{m}^{2}\right)$ in June. Global irradiance/ESR $\left(468.6 \mathrm{kWh} / \mathrm{m}^{2}\right)$ in June is 0.25 . Global irradiance $/ \mathrm{ESR}\left(300.6 \mathrm{kWh} / \mathrm{m}^{2}\right)$ in March is 0.35 . Therefore, the system usage rate of March is slightly higher than that of June. A similar outcome as March is also shown in November. This kind of BIPV system as a shade can be very well combined with a bi-facial PV cell rather than a mono facial solar cell. As reflected light and scattered light reach the rear and the front of the bi-facial solar cell, the module contributes to the power generation output, and the daily power at the same time as the instantaneous maximum power value increases. This is why most of 
the increase in the total solar radiation incident on the front and back of the bifacial solar cell module compared to the mono facial PV cell shows the output characteristics reflected by an increase in current. These results demonstrate the effective solar irradiance (ESR), consideration for power generation improvement, and continuity of ESR in Table 1.

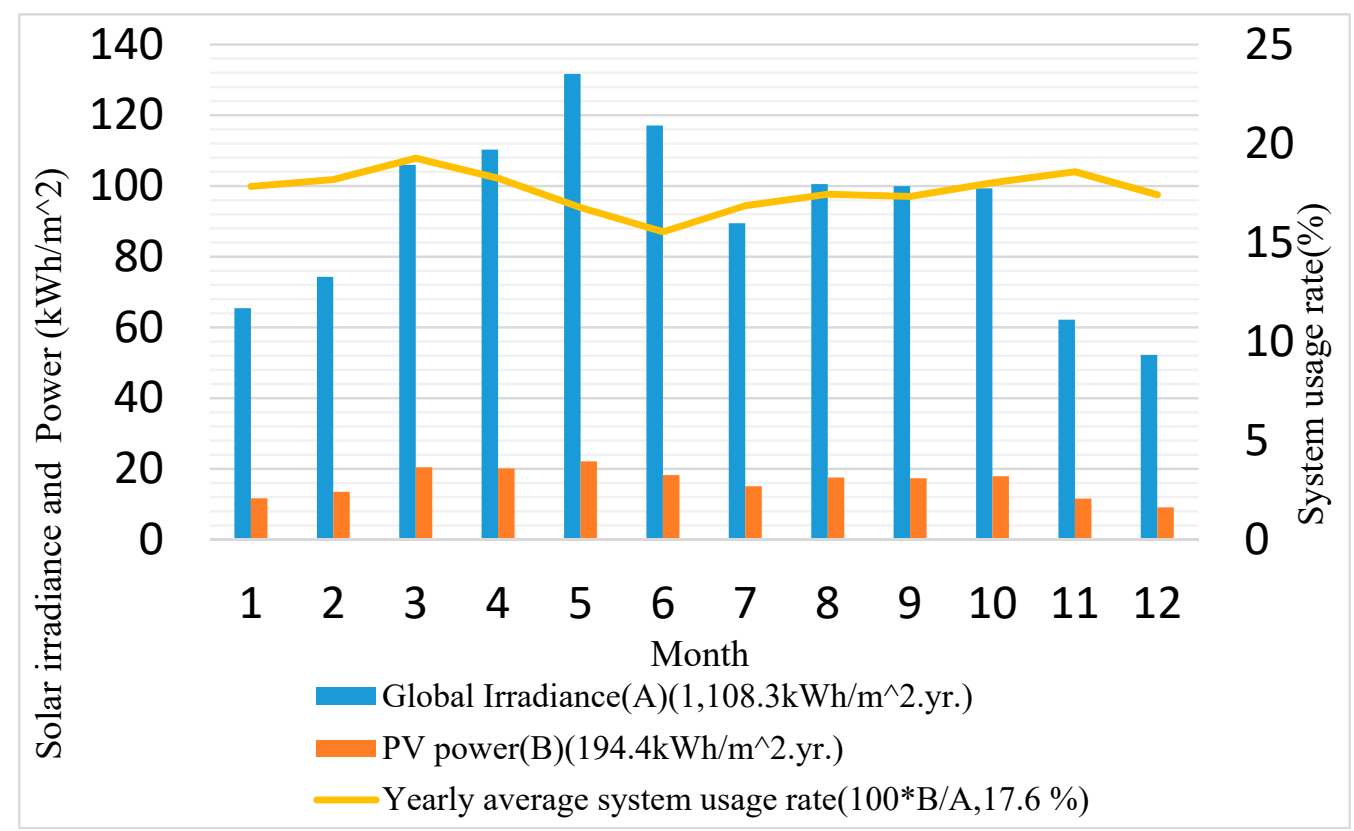

Figure 11. The system usage rate of the bi-facial BIPV module under the PV angle $23.5^{\circ}$.

Besides this added output of power generation, through the sun shading effect of this kind of BIPV system during the cooling period, there are interesting results regarding cooling load reduction. The energy demand for heating, cooling, hot water, lighting, and ventilation of the apartment is approximately $120.3 \mathrm{kWh} / \mathrm{m}^{2} \cdot \mathrm{yr}$. The heating energy consumption for the apartment was investigated at $187.01 \mathrm{kWh} / \mathrm{m}^{2} \cdot \mathrm{yr}$ and the electrical energy consumption for the apartment was investigated at $826.51 \mathrm{kWh} / \mathrm{m}^{2} . \mathrm{yr}$ [14]. The building energy consumption with an outer PV shade is decreased approximately 32 34\% compared to the building energy consumption without an outer PV shade [3]. Another research result for this art of shade PV system in Rome, Italy, was also shown to reduce the cooling load by $27.6 \%$ [15].

Overhang, light shelf, and louver reduce the solar gain from the exterior windows by approximately $29 \%, 53 \%$, and $70 \%$, respectively, over a year [16]. Based on the abovementioned calculation and research results, the energy consumption characteristic for the apartment can be demonstrated. Figure 12 shows the relation of the power generation and the apartment energy consumption between the two different types (BIPV as a shade and Wall attached) of PV systems.

Figure 12 demonstrates that the BIPV as a shade generates $46 \%$ more power than the wall-attached PV system, while it reduces $27.6 \sim 34 \%$ of the cooling load of an apartment as it plays the role of an eave. Without this shading device, after the solar irradiance passes through the glass window and reaches the floor or wall of the room, the wavelength becomes longer, so it cannot go out through the window in the form of radiation. As it continues to accumulate indoors, the cooling load greatly increases, so it is important to use it as a shading device.

These are reasons why the heating and cooling load of the building can be minimized through maximization of the total energy elimination factor in summer and the total energy transmittance factor in winter in the transparent envelope factor in Table 1 . These minimizations can be achieved by the application of the MB-BIPVS, having the eave function of traditional Korean architecture. 


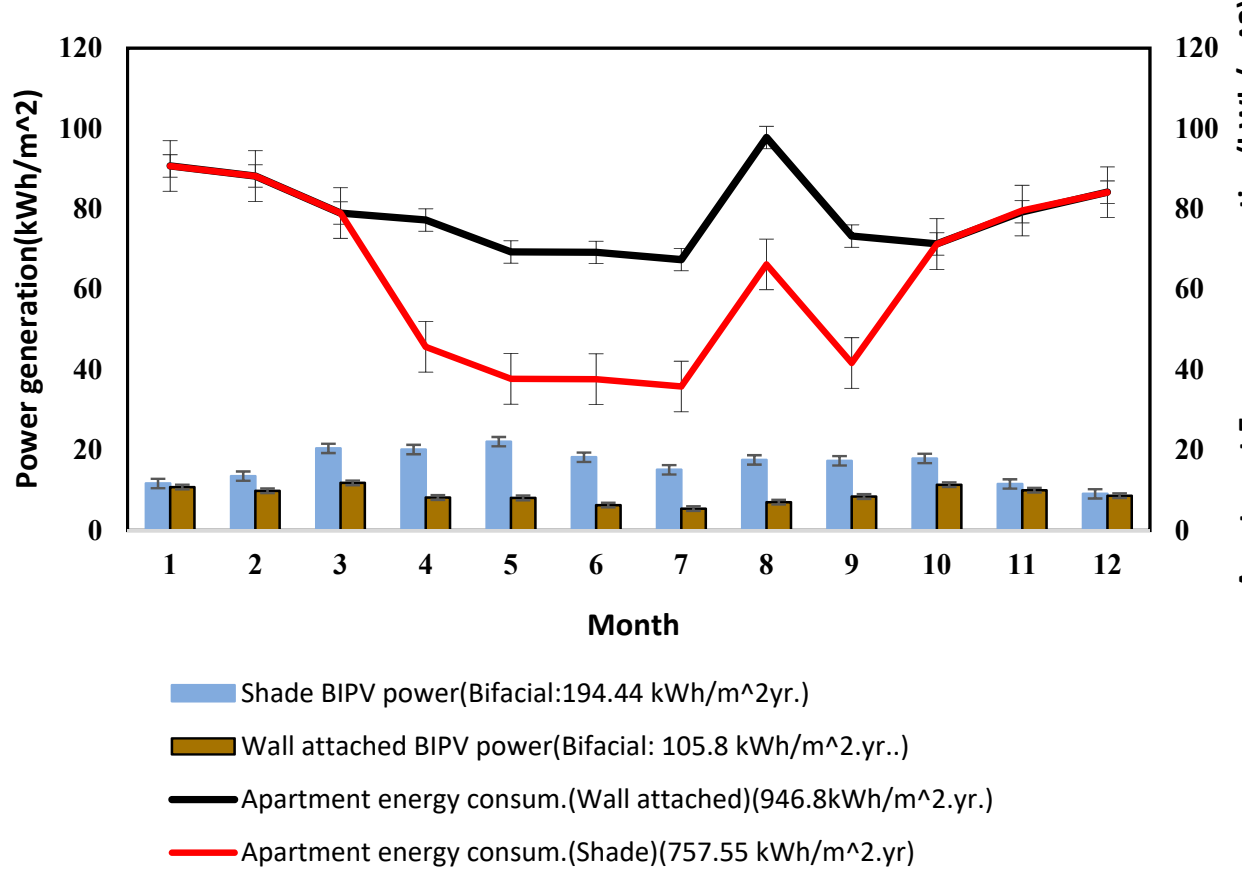

Figure 12. The power generation and the apartment energy consumption between the two different types of PV systems.

\section{Conclusions}

The main interest areas of the BIPV research are improving the solar cells and module efficiency, lifetime, cost, PV module's energy yield, and multi-functional use of the PV module to reduce the cost of power generation and the cooling load in summer. The ecological design criteria for solar architecture are deployed for a high-rise apartment building in which a bi-facial BIPV system as a shade is planned to optimize through some parameter variation.

The bi-facial BIPV as a shade can produce $12 \%$ additional power output in comparison to a conventional mono-facial BIPV system in a high-rise apartment building. The influence of the bi-facial PV module reflectance on power generation is approximately $0.9 \%$, much more than one of the mono-facial PV modules by $0.1 \%$ increased reflectance, when comparing the influence of PV module reflectance among various variables which can give influence on the power generation.

A change of PV cell reflectance and façade (wall and window) reflectance could cause a relatively significant impact on power generation in bi-facial PV systems as a shade. The optimum angle of MB-BIPVS is approximately $23.5^{\circ}$ considering the physical interaction, aesthetical view, and the traditional architecture in Korea. The ESR is very important not only for the PV efficiency but also for the system usage rate. The system usage rate is deeply related to consideration for Power Generation Improvement (PV surface temperature), ESR, total energy elimination factor, total energy transmittance factor, thermal comfort, continuity of ESR, and cleaning for the module surface, etc., in the ecological design criteria.

The MB-BIPVS should be controlled depending on the climate condition and architectural culture to maximize the total energy elimination factor and total energy transmittance factor for a window. The MB-BIPVS plays an excellent role in maximizing the total energy elimination factor and total energy transmittance factor for a window.

The system usage rate of the wall attached PV system demonstrates the seasonal big difference but shows just $5.4 \%$ in June which represents the highest solar altitude among 12 months. The yearly average system usage rate is also low for these reasons, corresponding to $9.5 \%$. The high system usage rate of the inclined PV system functions as a shade demonstrates a uniform distribution all year round independent of the seasonal change compared to the wall attached PV systems. The increased power output caused by 
the uniform system usage rate of the inclined bi-facial BIPV system is $46 \%$ more than one of the wall-attached BIPV system. Besides this added output of power generation, through the sun shading effect of this kind of BIPV system as a shade during the cooling period, the cooling load of the corresponding building is approximately reduced by, e.g., $27.6-34 \%$. The Solar Architecture Integrated bifacial Photovoltaic System should be designed as multipurpose, which can generate electricity and act as shade in a cooling period in a hot climate zone. It is necessary to examine the other variables (Table 2) that affect power generation, building energy consumption, and occupant comfort through parameter simulation during the design process to make a sustainable solar architecture in the future.

Author Contributions: S.-H.Y.: conceptualization, methodology, software, formal analysis, investigation, data curation, writing - original draft preparation; H.-J.C.: writing-review and editing, visualization, supervision, project administration. Both authors have read and agreed to the published version of the manuscript.

Funding: This research received no external funding.

Institutional Review Board Statement: Not applicable.

Informed Consent Statement: Not applicable.

Data Availability Statement: Not applicable.

Acknowledgments: The authors acknowledge the financial support of Sehan University.

Conflicts of Interest: The authors declare no conflict of interest.

\section{References}

1. Special Issue, Ecological Fusion of Green Home and Photovoltaic System. Rev. Archit. Build. Sci. 2011, 10.

2. Special Issue, Low Carbon Green Growth \& Photovoltaic in Architecture. Rev. Archit. Build. Sci. $2010,01$.

3. Yoo, S.H. Optimization of a BIPV system to mitigate greenhouse gas and indoor environment. Sol. Energy 2019, 8, 875-882. [CrossRef]

4. Special Issue, Ecological Fusion of Green Building and New Renewable Energy. Korea Green Build. Counc. $2011,12$.

5. Workshop for Dissemination and Assessment of an Environment Friendly PV Building; AIK-C-2010-02, 04; Architectural Institute of Korea: Seoul, Korea, 2010.

6. Symposium for Assessment and Certification of Passive Solar Photovoltaic Architecture; NREC of AIK, KSES, KSLES, KIAEBS and KOPIA: Seoul, Korea, 2011; Volume 6.

7. Hoseinzadeh, P.; Assadi, M.K.; Heidari, S.; Khalatbari, M.; Saidur, R.; Sangin, H. Energy performance of building integrated photovoltaic high-rise building: Case study. Tehran Iran Energy Build. 2021, 235, 110707. [CrossRef]

8. Yoo, S.H. Simulation for an optimal application of BIPV through parameter variation. Sol. Energy 2011, 85, 1291-1301. [CrossRef]

9. Yoo, S.H. Ecological criteria for optimization of solar architecture. In Energy Science and Technology Series. Solar Engineering; Studium Press, LLC.: Houston, TX, USA, 2015; Volume 5.

10. Chudinzow, D.; Haas, J.; Díaz-Ferrán, G.; Moreno-Leiva, S.; Eltrop, L. Simulating the energy yield of a bifacial photovoltaic power plant. Sol. Energy 2019, 183, 812-822. [CrossRef]

11. Appelbaum, J. Bifacial photovoltaic panels field. Sol. Energy 2016, 85, 338-343. [CrossRef]

12. Garcia, J.L.; Tony, A.C. Electrical performance of bifacial silicon PV modules under different indoor mounting configurations affecting the rear reflected irradiance. Sol. Energy 2019, 177, 471-482. [CrossRef]

13. Motuzienè, V.; Valančius, K. Multi-criteria assessment of building integrated photovoltaics. Environ. Prot. Eng. 2015, 7, 499-504.

14. An, T.K.; Kim, S.Y.; Kang, J.S.; Park, H.S. A study on energy consumption characteristic and estimation of apartment. Archit. Inst. Korea 1997, 9, 107.

15. Francesca, F.; Marco, L.; Cristina, C.; David, M.; Siani, M.; Maria, A. Use of photovoltaic modules as static solar shadings: Retrofit of a paleontological site in Rome. In Proceedings of the Conference on Advanced Building Skin 2017, Bern, Switzerland, 2 October 2017; Volume 10.

16. Balador, Z.; Imani, F.; Gjerde, M. Evaluation of different shading devices for a Tehran primary school classroom. In Proceedings of the PLEA 2017 EDINBURG, Edinburgh, UK, 2-5 July 2017. 